\title{
Influence of Fine Zirconia Particle Shot Peening on Sliding Wear of Zirconia-Silicon Carbide Composites
}

\author{
Hitonobu Koike, Koji Takahashi \\ Yokohama National University, Yokohama, Japan \\ Email: koike-hitonobu-rp@ynu.jp, takahashi-koji-ph@ynu.ac.jp
}

How to cite this paper: Koike, H. and Takahashi, K. (2017) Influence of Fine Zirconia Particle Shot Peening on Sliding Wear of Zirconia-Silicon Carbide Composites. Journal of Surface Engineered Materials and Advanced Technology, 7, 38-49. https://doi.org/10.4236/jsemat.2017.72004

Received: February 21, 2017

Accepted: April 27, 2017

Published: April 30, 2017

Copyright ( 92017 by authors and Scientific Research Publishing Inc. This work is licensed under the Creative Commons Attribution International License (CC BY 4.0).

http://creativecommons.org/licenses/by/4.0/

\begin{abstract}
In this paper, the sliding contact fatigue wear performance of shot-peened zirconia-silicon carbide composite $\left(\mathrm{ZrO}_{2} / \mathrm{SiC}\right)$ plates in contact with silicon nitride balls under compressive residual stress in dry conditions was investigated in order to improve the wear resistance of $\mathrm{ZrO}_{2} / \mathrm{SiC}$ friction parts. The wear resistance of $\mathrm{ZrO}_{2} / \mathrm{SiC}$ plates after shot peening was higher than that of plates not treated with shot peening in sliding wear testing under Hertziancontact. Due to fine Zirconia particle shot peening, the tetragonal phase crystal structure in $\mathrm{ZrO}_{2}$ in the near-surface of $\mathrm{ZrO}_{2} / \mathrm{SiC}$ plates was changed, and $1100 \mathrm{MPa}$ compressive residual stress could be introduced into the near-surface layer of $\mathrm{ZrO}_{2} / \mathrm{SiC}$ plates. The compressive residual stress was determined to be the main factor in the improvement of the sliding wear resistance of $\mathrm{ZrO}_{2} / \mathrm{SiC}$ plates.
\end{abstract}

\section{Keywords}

Sliding Fatigue Wear, $\mathrm{ZrO}_{2} / \mathrm{SiC}$ Composite, Shot-Peening, $\mathrm{X}$-Ray Spectroscopy

\section{Introduction}

Zirconia $\left(\mathrm{ZrO}_{2}\right)$ composites have great potential as moving parts in special situations for machine elements or medical apparatus. They have low densities, high hardness, high temperature durability and biocompatibility [1] [2] [3]. Particularly the wear resistance is one of the most important properties for moving parts such as bearing or joints. Because severe wear at the contact areas in friction zones of moving parts affects the device's lifespan and stable movement. Recently the tribological behavior on $\mathrm{ZrO}_{2}$ was studied by many researchers [4] [5] [6] in order to evaluate the quality problems such as failure of ceramic's part. Mechanical sliding wear of ceramics under dry conditions is a process of conti- 
nuous micro-fracturing from many cracks, in fact, sliding wear related to fracture toughness. Hokkirigawa [7] proposed that the sliding wear of ceramics is related to both $K_{\text {eff }}$ and $P_{\max }$ and crack length.

In order to improve the friction surface of $\mathrm{ZrO}_{2}$ composites reinforced by silicon carbide $\left(\mathrm{ZrO}_{2} / \mathrm{SiC}\right)$ for practical use, this study focused on shot peening (SP). SP is a well-known surface treatment technique for improving fatigue strength of metal parts. In a typical SP process, a stream of small, hard spheres is shot at a treated surface. After SP, compressive residual stress is generated underneath the treated surface, due to localized plastic deformation in the nearsurface layer. Pfeiffer et al. [8] found that compressive residual stress could also be introduced into the near-surface of silicon nitride $\left(\mathrm{Si}_{3} \mathrm{~N}_{4}\right)$ using a novel SP method. As a result of SP effects, the resistance of the bearing raceway against surface fatigue damage (severe pitting and chipping) increased [8]. Takahashi et al. [9] [10] [11] [12], in addition, reported that the compressive residual stress occurred in the near-surface region of shot-peened partially-stabilized zirconia (PSZ) [9], $\mathrm{Si}_{3} \mathrm{~N}_{4}$ [10] [11], or $\mathrm{Al}_{2} \mathrm{O}_{3}$ [12]. The compressive residual stresses at the PSZ and $\mathrm{Si}_{3} \mathrm{~N}_{4}$ surfaces after SP were approximately $1400 \mathrm{MPa}$ and $880 \mathrm{MPa}$, respectively. The compressive residual stresses significantly increased PSZ's fracture toughness and bending strength [9]. Koike et al. [13] stated the wear durability of PSZ after SP was better than that of PSZ without SP. However, the mechanism behind this increase in wear durability of $\mathrm{ZrO}_{2} / \mathrm{SiC}$ composites under compressive residual stress by SP stress was not clear.

Some researchers have reported phase transformation or domain switching as a result of the application of tensile or compressive stress. Tetragonal-to-monoclinic phase transformation [14] [15] and ferroelastic domain switching [16] [17] are well-known mechanisms for toughening of $\mathrm{ZrO}_{2}$. Mc Meeking et al. [15] presented that tetragonal-to-monoclinic phase transformation, for one, prevents crack propagation at the crack tip because of the crack closure effect. Kiguchi et al. [16] and Virkar et al. [17] reported the second mechanism as reorientation of ferroelastic domains by externally applied stress. Kiguchi et al. [16] stated that the application of compressive stress converted the $c$ axis into an $\boldsymbol{a}$ axis in lattice constants in the tetragonal phase of $\mathrm{ZrO}_{2}$.

As mentioned, the wear properties of shot-peened PSZ were investigated previously [13]. However, the effects of SP on the wear resistance of $\mathrm{ZrO}_{2} / \mathrm{SiC}$ composites have not been investigated yet. In addition, microstructural changes after SP, such as domain switching, are unclear. In this work, therefore, the sliding wear properties of the shot-peened $\mathrm{ZrO}_{2}$ reinforced by silicon carbide $\left(\mathrm{ZrO}_{2} /\right.$ $\mathrm{SiC}$ ) were examined under dry conditions. The near-surface of the $\mathrm{ZrO}_{2} / \mathrm{SiC}$ plates was examined by X-ray measurements in order to explore their microstructural changes after SP.

\section{Materials and Methods}

\subsection{Materials and Shot Peening Procedure}

$\mathrm{ZrO}_{2}$ reinforced by silicon carbide $\left(\mathrm{ZrO}_{2} / \mathrm{SiC}\right)$ was selected as the test material. 
Wear test specimens were fabricated from $\mathrm{ZrO}_{2}$ powder containing 3 mol$\% \mathrm{Y}_{2} \mathrm{O}_{3}$ and $20 \mathrm{vol} \% \mathrm{SiC}$ powders. After mixing of $\mathrm{ZrO}_{2} / \mathrm{SiC}$ with ethanol by ball milling for $24 \mathrm{~h}$, the powder was dried in a vacuum chamber. The dry powder was hotpressed under vacuum at $1450^{\circ} \mathrm{C}$ and $30 \mathrm{MPa}$ for $1 \mathrm{~h}$. The hot-pressed materials were cut into plates. The size of the $\mathrm{ZrO}_{2} / \mathrm{SiC}$ plates was $25 \mathrm{~mm} \times 25 \mathrm{~mm} \times 4$ $\mathrm{mm}$ (length $\times$ width $\times$ thickness). The density of this material was $6.05 \mathrm{~g} / \mathrm{cm}^{3}$. $\mathrm{ZrO}_{2} / \mathrm{SiC}$ plate specimens with and without SP are referred to as SP and Non-SP specimens. For SP, $\mathrm{ZrO}_{2}$ beads with a diameter of $180 \mu \mathrm{m}$, air pressure of 0.2 $\mathrm{MPa}$, and peening time of $20 \mathrm{~s}$ were used. SP coverage was approximately $200 \%$, meaning that the complete $\mathrm{ZrO}_{2} / \mathrm{SiC}$ plate surface was shot-peened twice. The brittle $\mathrm{ZrO}_{2} / \mathrm{SiC}$ were not cracked by the shots when the air pressure was lower than $0.2 \mathrm{MPa}$. It was suitable condition for compressive residual stress by SP. Finally, after SP, $\mathrm{ZrO}_{2} / \mathrm{SiC}$ plate surfaces were polished with a $0.1 \mu \mathrm{m}$ diameter diamond solution to truncate the edges on dimples caused by SP. The surface roughness of all samples was measured using a profilometer, with three repeated measurements per sample. The Vickers hardness (HV) of Non-SP and SP plates was measured by a hardness tester using a load of $98 \mathrm{~N}$ and indentation time of $20 \mathrm{~s}$.

\subsection{Sliding Contact Wear Test Setup}

Figure 1 illustrates the ball-on-plate sliding wear test at room temperature. $\mathrm{Si}_{3} \mathrm{~N}_{4}$ balls (grade 3) with $4.76 \mathrm{~mm}$ diameter and Vickers hardness of $1600 \mathrm{HV}$ were used as wear counterparts. Sliding wear tests were performed by using a friction wear test machine in reciprocation mode, with a reciprocation length of $10 \mathrm{~mm}$. The vertical loads $Q$ ranged from 2.94 to $9.80 \mathrm{~N}$, corresponding to a mean Hertzian contact pressure $\left(P_{\text {mean }}\right)$ ranging between 816 and $1219 \mathrm{MPa}$. The maximum Hertzian contact pressures $P_{\max }$ ranged between 1220 and $1830 \mathrm{MPa}$. Values for $P_{\text {mean }}$ and $P_{\max }$ were calculated from the following equations [18].

$$
\begin{gathered}
a=\sqrt[3]{\frac{3 R Q}{4}\left\{\frac{\left(1-v_{1}^{2}\right)}{E_{1}}+\frac{\left(1-v_{2}^{2}\right)}{E_{2}}\right\}} \\
P_{\text {mean }}=\frac{Q}{\pi a^{2}}, P_{\text {max }}=1.5 P_{\text {mean }}
\end{gathered}
$$

In the above, $v_{1}$ and $v_{2}$ are the Poisson's ratios for ball and plate materials, respectively; $v_{1}=0.28$ and $v_{2}=0.28 . E_{1}$ and $E_{2}$ are the Young's moduli for ball and plate materials, respectively; $E_{1}=300 \mathrm{GPa}$ and $E_{2}=214 \mathrm{GPa} . Q[\mathrm{~N}]$ is the vertical load, $a[\mathrm{~m}]$ is the contact area radius, and $R$ is the ball radius. The sliding velocity and frequency were $0.033 \mathrm{~m} / \mathrm{s}$ and $1.7 \mathrm{~Hz}$, which corresponds to 100 reciprocation cycles per minute. The total wear path length and total duration were $800 \mathrm{~m}$ and $400 \mathrm{~min}$, respectively. In order to calculate the wear volume $\left(W_{\mathrm{vol}}\right)$ of $\mathrm{ZrO}_{2} / \mathrm{SiC}$ plates after the test, the wear depth $\left(W_{\text {dep }}\right)$ and width $\left(W_{\text {wid }}\right)$ were measured at three different areas of each specimen using a profilometer. Equation (3) was used to calculate $W_{\text {vol }}$.

$$
W_{\text {vol }}=0.5 \times W_{\text {dep }} \times W_{\text {wid }} \times 10
$$



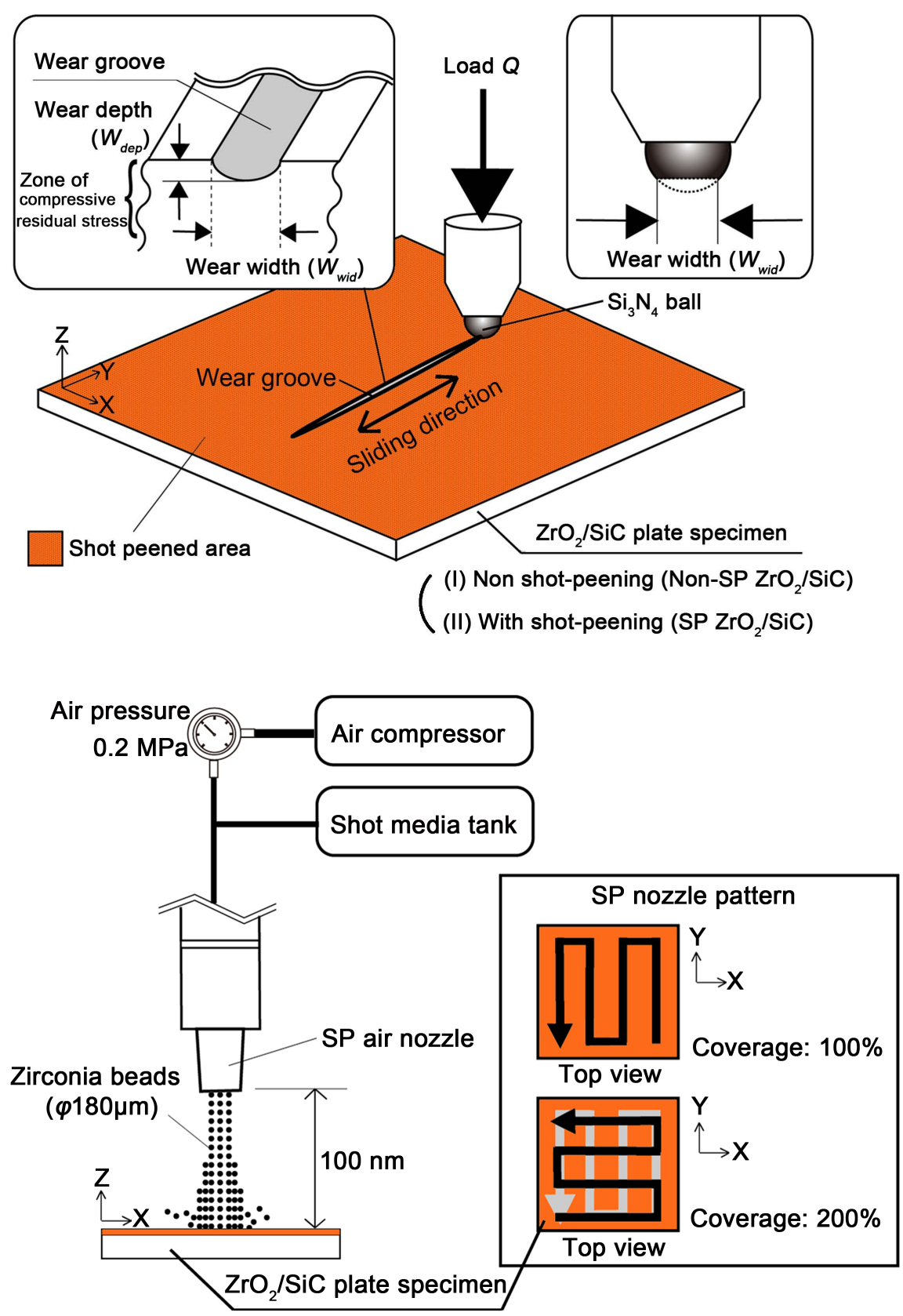

Figure 1. Schematic illustration of the sliding wear test in reciprocation mode, and shot peening pattern.

In the above, the cross-sectional area of the wear groove was approximated as a triangular area $\left(=0.5 \times W_{\text {dep }} \times W_{\text {wid }}\right)$, which was multiplied by the reciprocation length $(10 \mathrm{~mm})$. The ball and plate specimens prior to and after the tests were observed using an optical microscope with polarized light.

\subsection{XRD Measurements}

To evaluate residual stress and crystal structures at the near-surface of $\mathrm{ZrO}_{2} / \mathrm{SiC}$ plates, XRD measurements were taken. Table 1 lists the conditions for measurement of residual stress, which was estimated using the $2 \theta-\sin ^{2} \Psi$ method. 
Table 1. Conditions of residual stress measurements.

\begin{tabular}{|c|c|}
\hline $\mathrm{X}$-ray diffraction (XRD) equipment & Ultima IV (Rigaku corp.) \\
\hline Characteristic X-ray & $\mathrm{CrK} \alpha$ (For residual stress of ( $\left(\begin{array}{lll}1 & 3 & 3\end{array}\right)$ plane) \\
\hline Diffraction plane & tetragonal ( $\left.\begin{array}{llll}1 & 3 & 3\end{array}\right)$ \\
\hline Diffraction angle (deg) & 153.50 \\
\hline $\mathrm{X}$-ray stress constant $(\mathrm{MPa} / \mathrm{deg})$ & $-283[19]$ \\
\hline Tube voltage $(\mathrm{kV})$ & 40 \\
\hline Tube current (mA) & 40 \\
\hline
\end{tabular}

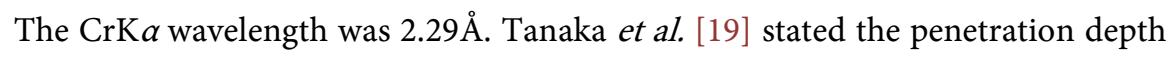
of $\mathrm{CrK} \alpha$ radiation was estimated as $2-3 \mu \mathrm{m}$.

\section{Experimental Results and Discussion}

\subsection{Surface Observation after Shot-Peening}

Figure 2 shows optical microscope and scanning probe microscope (SPM) images of Non-SP and SP plates. Submicron-sized dimples were formed on the surface of the $\mathrm{SP} \mathrm{ZrO}_{2} / \mathrm{SiC}$ plates by the impact of the $\mathrm{ZrO}_{2}$ beads. Table 2 shows the average roughness $\left(R_{\mathrm{a}}\right)$ and maximum roughness height $\left(R_{\mathrm{z}}\right)$ of Non-SP and SP plates. The $R_{\mathrm{a}}$ values of the SP plates after polishing and the Non-SP plates were identical. The $R_{z}$ of the SP plate after polishing was $0.73 \mu \mathrm{m}$, slightly higher than that of the Non-SP plate $\left(R_{\mathrm{z}}=0.57 \mu \mathrm{m}\right)$, due to the fact that the submicron-sized dimples induced by SP were not completely removed by polishing.

\subsection{Hardness}

The HV of Non-SP and SP $\mathrm{ZrO}_{2} / \mathrm{SiC}$ plates was $1260 \mathrm{HV}$ and $1398 \mathrm{HV}$, respec-

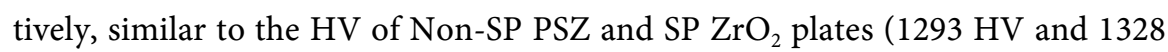
HV, respectively) [13]. SP thus caused an increase in HV of both materials [9] [13]. It was thought that the hardness of both materials increased because strain hardening or recrystallization occurred due to SP. Figure 3 shows microscopic images of Vickers indentations on the surfaces of Non-SP and $\mathrm{SP} \mathrm{ZrO}_{2} / \mathrm{SiC}$ plates. The apparent fracture toughness of the Non- $\mathrm{SPZrO}_{2} / \mathrm{SiC}$ plate was calculated $8.9 \mathrm{MPa} \cdot \mathrm{m}^{0.5}$ by Indentation Fracture method. However, no radial cracks were formed on the $\mathrm{SP} \mathrm{ZrO}_{2} / \mathrm{SiC}$ plates due to the effects of compressive residual stress, indicating that the apparent fracture toughness of $\mathrm{ZrO}_{2} / \mathrm{SiC}$ plates was improved by SP.

\subsection{Sliding Wear Test}

Figure 4(a) shows optical microscope image of friction surface on the raceway of shot-peened $\mathrm{ZrO}_{2} / \mathrm{SiC}$ plate after the wear test at $P_{\text {mean }}=967 \mathrm{MPa}$. Microplowings can be observed on both the SP and Non-SP plates. These microplowings were caused by traction of wear particles. Abrasive wear was main wear mechanism in the tests. Adhesive wear was rarely observed. Figure 4(b) shows the optical microscope image of friction surface on the $\mathrm{Si}_{3} \mathrm{~N}_{4}$ balls after wear 



Figure 2. Optical microscope (left) and surface topography (right) prior to the test: (a) Non-SP, (b) SP.


Figure 3. Vickers indentation and radial cracks; (a) Non-SP plate, (b) SP plate.

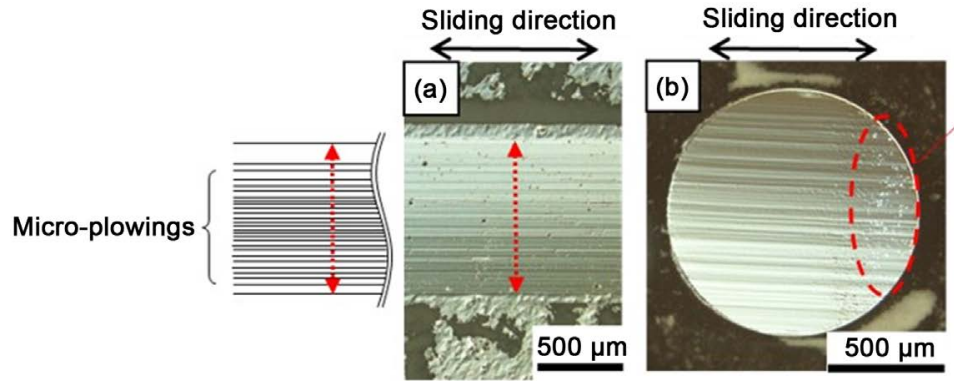

Wear particles

Figure 4. Optical micrographs of the friction surfaces; (a) raceway of the shot-peened $\mathrm{ZrO}_{2} / \mathrm{SiC}$ plate and (b) the $\mathrm{Si}_{3} \mathrm{~N}_{4}$ ball after $8 \times 10^{4}$ cycles at $P_{\text {mean }}=967 \mathrm{MPa}$. Note that the dot-lined arrows indicate the $W_{\text {wid }}$.

Table 2. Surface roughness of Non-shot-peened (Non-SP) and shot-peened (SP) plates.

\begin{tabular}{rcc}
\hline & Non-SP & SP \\
\hline Average roughness, $R_{a}(\mu \mathrm{m})$ & 0.04 & 0.04 \\
Maximum height roughness, $R_{z}(\mu \mathrm{m})$ & 0.57 & 0.73 \\
\hline
\end{tabular}

testing. Micro-plowings and wear particles can be observed, similar as on the $\mathrm{ZrO}_{2} / \mathrm{SiC}$ plates. Powder-like wear particles accumulated on the sliding area near the edge of the balls. These wear particles caused micro- plowings along sliding tracks on the friction surfaces of both balls and plates.

Figure 5 shows the $W_{\text {vol }}$ values of $\mathrm{ZrO}_{2} / \mathrm{SiC}$ plates after $8 \times 10^{4}$ cycles. The $W_{\text {vol }}$ of the $\mathrm{SP} \mathrm{ZrO}_{2} / \mathrm{SiC}$ plates clearly smaller than that of Non-SP plates. Figure 6 shows the $W_{\text {wid }}$ of the $\mathrm{Si}_{3} \mathrm{~N}_{4}$ balls after $8 \times 10^{4}$ cycles. The $W_{\text {wid }}$ values of the $\mathrm{Si}_{3} \mathrm{~N}_{4}$ balls used for tests on the SP plates were lower than those of balls used for tests on Non-SP plates. The aggressiveness to $\mathrm{Si}_{3} \mathrm{~N}_{4}$ balls was also reduced when 




Figure 5. Comparison of plate wear volume for SP and Non-SP $\mathrm{ZrO}_{2} / \mathrm{SiC}$ plates after $8 \times$ $10^{4}$ cycles.

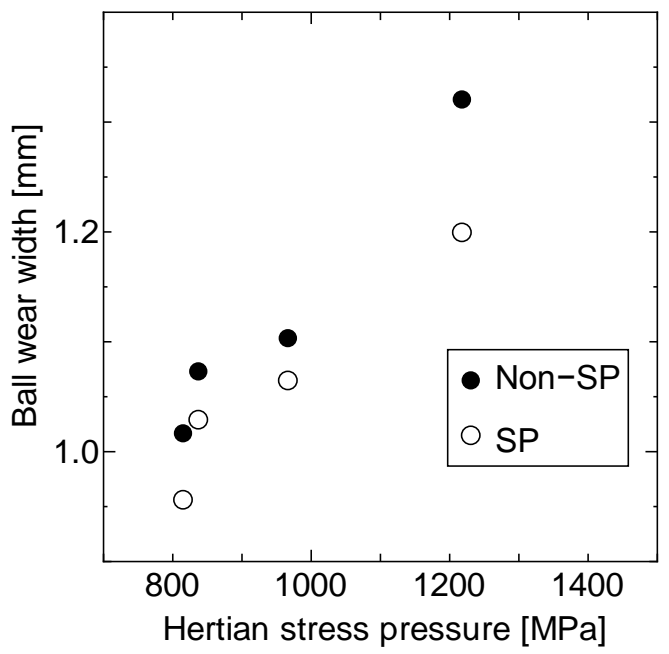

Figure 6. Comparison of wear width $\left(W_{\text {wid }}\right)$ of $\mathrm{Si}_{3} \mathrm{~N}_{4}$ ball tested against SP and Non-SP $\mathrm{ZrO}_{2} / \mathrm{SiC}$ plates after $8 \times 10^{4}$ cycles.

the shot-peened $\mathrm{ZrO}_{2} / \mathrm{SiC}$ plates were polished. Thus, SP increased the sliding fatigue wear resistance of the $\mathrm{ZrO}_{2} / \mathrm{SiC}$ plates and the $\mathrm{Si}_{3} \mathrm{~N}_{4}$ balls.

Figure 7 shows the friction coefficients of the SP and Non-SP plates during wear testing at $P_{\text {mean }}=967 \mathrm{MPa}$. Each diamond symbol represents the average value of the friction coefficient during $2 \times 10^{4}$ reciprocation cycles. The average frictional coefficients of SP and Non-SP plates were almost identical at 0.65 and 0.63 , respectively. Thus, the submicron-sized dimples on the surface of SP $\mathrm{ZrO}_{2} /$ $\mathrm{SiC}$ plates shown in Figure 2(b) had little influence on the friction performance.

\subsection{XRD Measurements}

The measured value of compressive residual stress on the surface of SP $\mathrm{ZrO}_{2} / \mathrm{SiC}$ plates was approximately $1100 \mathrm{MPa}$ as shown in Figure 8. The compressive residual stress of $\mathrm{ZrO}_{2} / \mathrm{SiC}$ was higher than that of $\mathrm{Si}_{3} \mathrm{~N}_{4} / \mathrm{SiC}$ or $\mathrm{Al}_{2} \mathrm{O}_{3} / \mathrm{SiC}$. The 


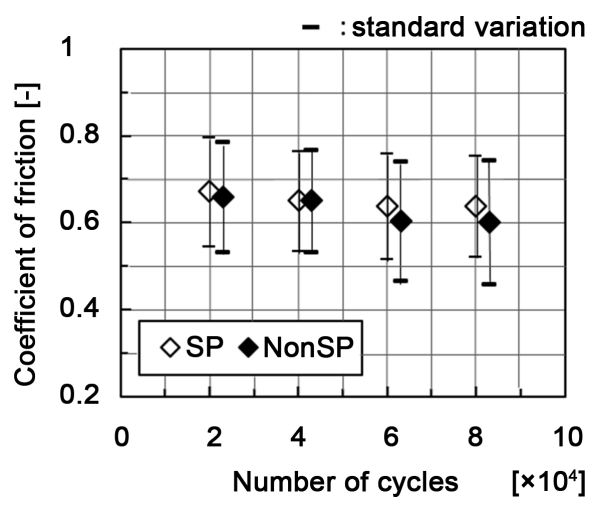

Figure 7. Friction coefficients of Non-SP and $\mathrm{SP} \mathrm{ZrO}_{2} / \mathrm{SiC}$ plates in contact with an $\mathrm{Si}_{3} \mathrm{~N}_{4}$ ball at $P_{\text {mean }}=967 \mathrm{MPa}$.

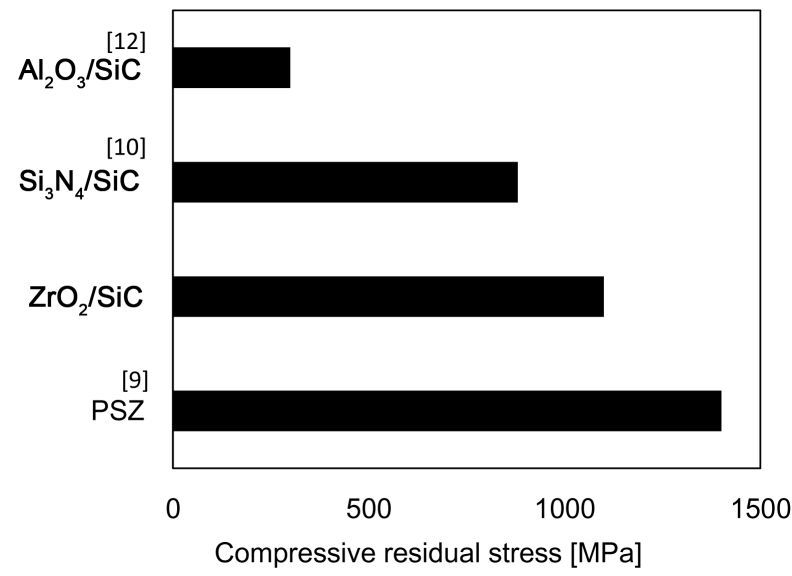

Figure 8. Compressive residual stress of the $\mathrm{ZrO}_{2} / \mathrm{SiC}$ plate surfaces.

compressive residual stress on the surface of PSZ was $1400 \mathrm{MPa}$ [9]. Thus, the compressive residual stress of $\mathrm{ZrO}_{2} / \mathrm{SiC}$ was lower than that of PSZ, even though the SP conditions were almost the same. It is thought that the SiC particles between the grain boundaries of $\mathrm{ZrO}_{2}$ locally restrained plastic deformation of $\mathrm{ZrO}_{2}$.

Figure 9 show the XRD profiles in the near-surface regions of $\mathrm{ZrO}_{2} / \mathrm{SiC}$ plates. The monoclinic (-111) peak after SP was only slightly detected. This means that tetragonal-to-monoclinic phase transformation was not main reason of large compressive stress on the $\mathrm{ZrO}_{2} / \mathrm{SiC}$ plate surfaces in the SP condition. However, The peaks around $2 \theta=35^{\circ}$, corresponding to tetragonal phases in $\mathrm{ZrO}_{2}$ crystal structure, changed after SP [20]. The relative integrated intensities of the tetragonal (002) peak and the tetragonal (200) peak changed after SP, as shown in Figure 9. The peak intensity ratios $(X)$ for Non-SP and SP specimens were calculated according to Equation (4).

$$
X=\frac{I_{t}(002)}{I_{t}(200)}
$$

In the above, $I_{\mathrm{t}}(002)$ and $I_{\mathrm{t}}(200)$ are peak intensities of the tetragonal (002) at $2 \theta=34.7^{\circ}$ and (200) at $2 \theta=35.2^{\circ}$, respectively. The $X$ for Non-SP and SP plates 

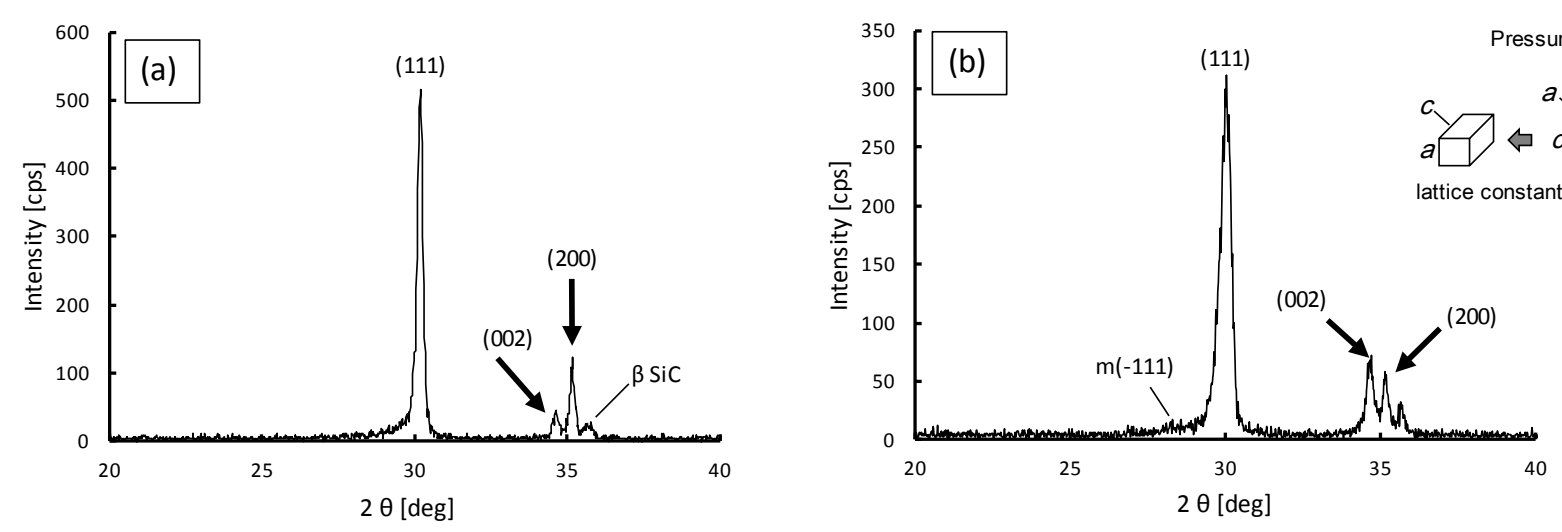

Figure 9. XRD measurements of the $\mathrm{ZrO}_{2} / \mathrm{SiC}$ plate surfaces; (a) Non-SP, (b) SP. Note that arrows are reference points.

was 0.303 and 1.412, respectively. The $X$ for the SP plates was therefore $466 \%$ higher than that for Non-SP plates. Thus, the lattice constants of tetragonal phase in $\mathrm{ZrO}_{2}$ were changed due to SP. This means that the lattice strain in the tetragonal phase in $\mathrm{ZrO}_{2}$ increased after SP, which is one of the reasons that large compressive residual stress could be introduced into the near-surface of the $\mathrm{ZrO}_{2}$ specimens. This phenomenon was considered to be the switching of lattice constants ( $\boldsymbol{a}$ and $\boldsymbol{c}$ in Figure 10) due to compressive contact stress during SP, likely causing toughening in $\mathrm{ZrO}_{2}$ due to ferroelastic domain switching [16]. Upon compressive residual stress generation in $\mathrm{ZrO}_{2}$, several mechanisms are proposed to take place; plastic deformation, phase transformation or domain switching. In $\mathrm{ZrO}_{2} / \mathrm{SiC}$ plates under $\mathrm{SP}$ conditions, it is thought that domain switching was one of the main mechanism of residual stress generation. Virkar et al. stated that the application of compressive stress exceeding $1650 \mathrm{MPa}$ along the $c$ axis converts the $c$ axis to an $\boldsymbol{a}$ axis, while one of the $\boldsymbol{a}$ axes converts to a $c$ axis [17]. Tanaka et al. [19] and Scott [21] reported that the lattice constants in tetragonal crystalline PSZ were $\boldsymbol{a}=0.510 \mathrm{~nm}$ and $c=0.519 \mathrm{~nm}$, respectively. In fact, due to contact stress of SP, the $c$ axis in the tetragonal phase converts to an $\boldsymbol{a}$ axis, and correspondingly the $\boldsymbol{a}$ axis stretched into a $\boldsymbol{c}$ axis. As the $\boldsymbol{c}$ axis of the tetragonal phase in $\mathrm{ZrO}_{2}$ was shortened by $0.009 \mathrm{~nm}$ along the compressive direction, the lattice constant changed: the (200) $c$ axis was converted to (002) as shown in Figure 9. Thus ferroelastic domain switching as the lattice constant change in the tetragonal phase in $\mathrm{ZrO}_{2}$ affects the large compressive residual stress generation.

\subsection{Sliding Wear of $\mathrm{ZrO}_{2} / \mathrm{SiC}$ under Compressive Residual Stress}

Figure 11 illustrates the wear particle contact abrasion model. Micro-plowing occurred due to wear particle indentation and abrasion between the $\mathrm{Si}_{3} \mathrm{~N}_{4}$ balls and the $\mathrm{ZrO}_{2} / \mathrm{SiC}$ plates. The wear particles were formed by fractures from micro-sized radial cracks, micro-flaking, or micro-pitting in the near-surface of the plates. Continuous micro-flaking affects the increasing amount of wear of the $\mathrm{ZrO}_{2} / \mathrm{SiC}$ plate. When compressive residual stress is introduced into the near-surface of the $\mathrm{SP} \mathrm{ZrO}_{2} / \mathrm{SiC}$ plates, radial cracks can be closed. Cracks are, 


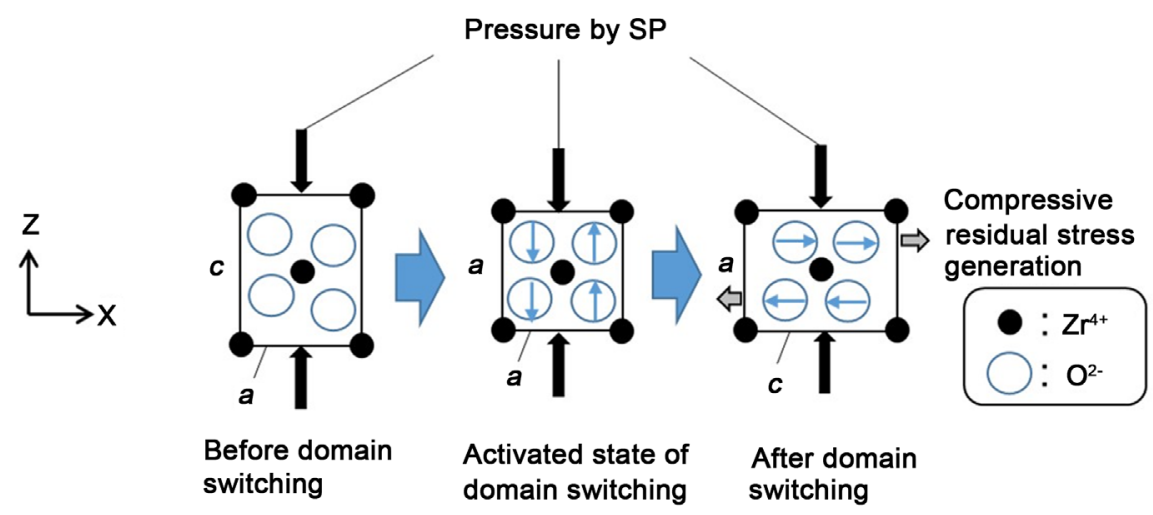

Figure 10. Schematic diagram of ferroelastic domain switching by SP. Note that the domain switching theory is cited from reference [16].

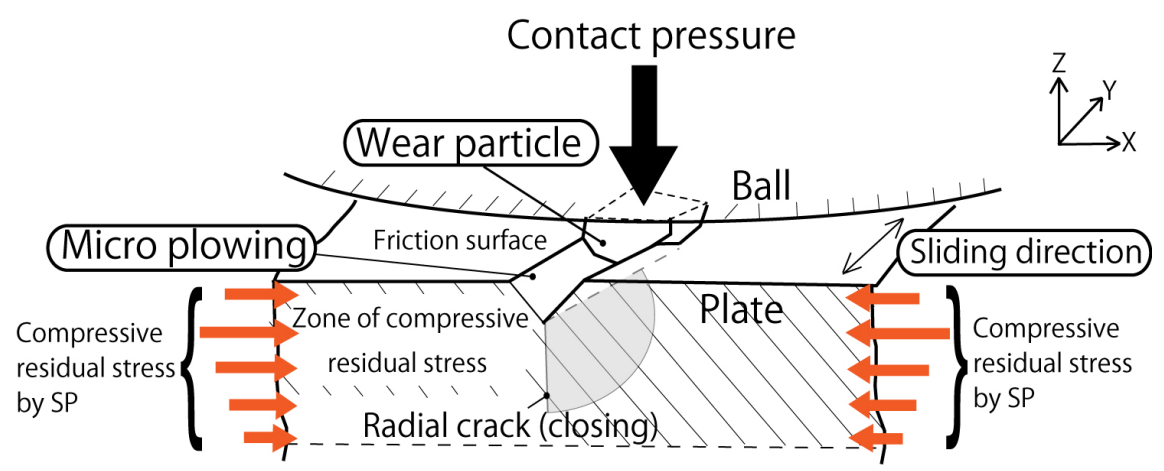

Figure 11. Improvement mechanism of sliding fatigue wear of the $\mathrm{ZrO}_{2} / \mathrm{SiC}$ plates under compressive residual stress. Note that radial cracks could be closed by compressive residual stress.

thus, arrested by the closure effect due to compressive residual stress, which is the mechanism behind the improvement of wear resistance in $\mathrm{SP} \mathrm{ZrO}_{2} / \mathrm{SiC}$ composite ceramics. Additionally, the large compressive residual stress related to plastic deformation and ferroelastic domain switching affects wear resistance on the $\mathrm{ZrO}_{2} / \mathrm{SiC}$ plate. As noted in 3.2. Hardness section, the apparent fracture toughness and hardness increased due to SP. These properties are also related to compressive residual stress, and improve the wear resistance at the $\mathrm{ZrO}_{2} / \mathrm{SiC}$ plate surface. From the above results and discussion, it can be concluded that SP increased the wear resistance of $\mathrm{ZrO}_{2} / \mathrm{SiC}$ plates against $\mathrm{Si}_{3} \mathrm{~N}_{4}$ ball in the sliding wear test by increasing the compressive residual stress.

\section{Conclusions}

In order to improve the sliding fatigue wear resistance of Zirconia-Silicon Carbide Composites $\left(\mathrm{ZrO}_{2} / \mathrm{SiC}\right)$ for frictional parts, the surface of $\mathrm{ZrO}_{2} / \mathrm{SiC}$ plates was strengthened by shot peening (SP). Shot-peened plates were evaluated through sliding wear tests using a mean Hertzian contact pressure ranging from 816 to $1219 \mathrm{MPa}$, and the compressive residual stress and profile were examined using X-ray diffraction. From the obtained experimental results, the following conclusions were drawn: 
1) The sliding fatigue wear resistance of shot-peened $\mathrm{ZrO}_{2} / \mathrm{SiC}$ plates against $\mathrm{Si}_{3} \mathrm{~N}_{4}$ balls was better than that of Non-SP plates. The aggressiveness to $\mathrm{Si}_{3} \mathrm{~N}_{4}$ balls was also reduced when the shot-peened $\mathrm{ZrO}_{2} / \mathrm{SiC}$ plates were polished.

2) SP could introduce a compressive residual stress of approximately 1100 $\mathrm{MPa}$ in the near-surface of $\mathrm{ZrO}_{2} / \mathrm{SiC}$ plates. This compressive residual stress improved the sliding fatigue wear resistance against radial cracks. In addition, the surface hardness of $\mathrm{ZrO}_{2} / \mathrm{SiC}$ plates also increased.

3) Due to SP, the $\mathrm{XRD}$ profile in the near-surface of the $\mathrm{ZrO}_{2} / \mathrm{SiC}$ plates changed; the lattice constants in the tetragonal phase shortened in the compressive direction. Domain switching was one of the main mechanisms of large compressive residual stress generation in the near-surface of the plates. This microstructural change effectively closes radial cracks in the $\mathrm{ZrO}_{2} / \mathrm{SiC}$ plates, which improve the sliding fatigue wear resistance of $\mathrm{ZrO}_{2} / \mathrm{SiC}$ plates.

\section{Acknowledgements}

The author would like to give special thanks to Dr. K. Houjou at National Institute of Technology, Oyama College and Dr. M. Yokouchi at Kanagawa Industrial Technology Center for specimen production, and Mr. K. Okayasu at Yokohama National University for X-ray measurement support in the Instrument Analysis Center. This work was supported by JSPS KAKENHI Grant Number JP25289003.

\section{References}

[1] Harrer, W., Deluca, M. and Morrell, R. (2014) Failure Analysis of a Ceramic Ball Race Bearing Made of Y-TZP Zirconia. Engineering Failure Analysis, 36, 262-268.

[2] Preis, V., Behr, M., Handel, G., Schneider-Feyrer, S., Hahnel, S. and Rosentritt, M. (2012) Wear Performance of Dental Ceramics after Grinding and Polishing Treatments. Journal of the Mechanical Behavior of Biomedical Materials, 10, 13-22.

[3] Aboushelib, M.N. (2010) Long Term Fatigue Behavior of Zirconia Based Dental Ceramics. Materials, 3, 2975-2985. https://doi.org/10.3390/ma3052975

[4] Kato, K. (2000) Wear in Relation to Friction-A Review. Wear, 241, 151-157.

[5] Adachi, K., Kato, K. and Chen, N. (1997) Wear Map of Ceramics. Wear, 203-204, 291-301.

[6] Kato, K. and Adachi, K. (2002) Wear of Advance Ceramics. Wear, 253, 1097-1104.

[7] Hokkirigawa, K. (1991) Wear Mode Map of Ceramics. Wear, 151, 219-228.

[8] Pfeiffer, W. and Frey, T. (2006) Strengthening of Ceramics by Shot Peening. Journal of the European Ceramic Society, 26, 2639-2645.

[9] Takahashi, K., Iwanaka, K., Osada, T. and Koike, H. (2015) Increase in Strength of Partially Stabilized Zirconia after Shot Peening. Journal of Materials Engineering and Performance, 24, 9, 3573-3578. https://doi.org/10.1007/s11665-015-1623-x

[10] Takahashi, K., Nishio, Y., Kimura, Y. and Ando, K. (2010) Improvement of Strength and Reliability of Ceramics by Shot Peening and Crack Healing. Journal of the European Ceramic Society, 30, 3047-3052.

[11] Takahashi, K. and Nishio, Y. (2012) Improvement of the Contact Strength of $\mathrm{Si}_{3} \mathrm{~N}_{4} / \mathrm{SiC}$ by a Comparison of Shot Peening and Crack-Healing. Journal of Solid Mechanics and Materials Engineering, 6, 144-153.

https://doi.org/10.1299/jmmp.6.144 
[12] Oki, T., Yamamoto, H., Osada, T. and Takahashi, K. (2013) Improvement of the Contact Strength of $\mathrm{Al} 2 \mathrm{O} 3 / \mathrm{SiC}$ bya Combination of Shot Peening and CrackHealing. Journal of Powder Technology, 2013, Article ID: 946984. https://doi.org/10.1155/2013/946984

[13] Koike, H., Iwanaka, K. and Takahashi, K. (2014) Measurement of Sliding Wear of Shot-Peened Partially Stabilized Zirconia Plate. Applied Mechanics and Materials, 597, 353-357. https://doi.org/10.4028/www.scientific.net/AMM.597.353

[14] Guazzato, M., Albakry, M., Ringer, S.P. and Swain, M.V. (2004) Strength, Fracture Toughness and Microstructure of a Selection of All-Ceramic Materials. Part II. Zirconia-Based Dental Ceramics. Dental Materials, 20, 5, 449-56.

[15] McMeeking, R.M. and Evans, A.G. (1982) Mechanics of Transformation-Toughening in Brittle Materials. Journal of the American Ceramic Society, 65, 242. https://doi.org/10.1111/j.1151-2916.1982.tb10426.x

[16] Kiguchi, T., Urushihara, W., Saiki, A., Shinozaki, K. and Mizutani, N. (1996) Effect of Stress and Temperature on Ferroelastic Domain Switching of Partially Stabilized Zirconia Pseudo-Single Crystals. Journal of the Ceramic Society of Japan, 104, 529-534. (In Japanese) https://doi.org/10.2109/jcersj.104.529

[17] Virkar, A.V. and Matsumoto, R.L.K. (1986) Ferroelastic Domain Switching as a Toughening Mechanism in Tetragonal Zirconia. Journal of the American Ceramic Society, 69, C224-C226. https://doi.org/10.1111/j.1151-2916.1986.tb07341.x

[18] Hertz, H. (1881) Über die Berührung fester elastischerKörper. Journal Für die Reine und Angewandte Mathematik, 92, 156-171. http://eudml.org/doc/148490

[19] Tanaka, K., Kurimura, T., Akiniwa, Y., Suzuki, K. and Nakagawa, H. (1989) X-Ray Residual Stress Measurement of Yttria-Partially Stabilized Zirconia. Transactions of the Japan Society of Mechanical Engineers, 55, 318-325. (In Japanese) https://doi.org/10.1299/kikaia.55.318

[20] Houjou, K. and Takahashi, K. (2012) Crack-Healing Behavior of $\mathrm{ZrO}_{2} / \mathrm{SiC}$ Composite Ceramics and Strength Properties of Crack-Healing Specimens. International Journal of Structural Integrity, 3, 41-52. https://doi.org/10.1108/17579861211209984

[21] Scott, H.G. (1975) Phase Relationships in the Zirconia-Yttria System. Journal of Material Science, 10, 1527-1535. https://doi.org/10.1007/BF01031853

Submit or recommend next manuscript to SCIRP and we will provide best service for you:

Accepting pre-submission inquiries through Email, Facebook, LinkedIn, Twitter, etc. A wide selection of journals (inclusive of 9 subjects, more than 200 journals)

Providing 24-hour high-quality service

User-friendly online submission system

Fair and swift peer-review system

Efficient typesetting and proofreading procedure

Display of the result of downloads and visits, as well as the number of cited articles

Maximum dissemination of your research work

Submit your manuscript at: http://papersubmission.scirp.org/

Or contact jsemat@scirp.org 